ANUVA Volume 2 (4): 413-428, 2018

Copyright (C2018, ISSN: 2598-3040 online

Available Online at: http://ejournal.undip.ac.id/index.php/anuva

\title{
Inovasi Sebagai Solusi pada Implementasi Kebijakan Penyelenggaraan Kearsipan
}

\author{
Tri Handayani ${ }^{*}{ }^{*}$ \\ ${ }^{1}$ Program Studi Ilmu Sejarah, Fakultas Ilmu Budaya, Universitas Diponegoro \\ ${ }^{*}$ Korespondensi: tri.handayani.undip@gmail.com
}

\begin{abstract}
Innovation is a creativity of a person or group of people so as to create a new work on a field. In the context of public administration, innovation is carried out by public organizations to provide better service to the public. Archives are recorders of information in various forms of information storage media. Archives that record information related to the public need to be managed with an archival system that is in line with archival legislation. A set of archival systems is required in the archival legislation to implement the policy. The aim is so that the interests of the state and public rights are protected. This study was conducted using the Archival Management and Public Administration approach. The results of the study are several archival aspects problems in public organizations in Indonesia can be given a solution to the innovation of archival policies
\end{abstract}

Keywords: archives; information; innovation; management; public administration; public organizations; public service

\begin{abstract}
Abstrak
Inovasi merupakan suatu kreatifitas seseorang atau sekelompok orang sehingga menciptakan suatu karya baru pada suatu bidang. Dalam konteks administrasi publik, inovasi dilakukan oleh organisasi publik untuk memberikan pelayanan yang lebih baik kepada publik. Arsip merupakan perekam informasi dalam berbagai bentuk media penyimpan informasi. Arsip yang merekam informasi terkait publik perlu dikelola dengan sistem kearsipan yang sejalan dengan perundang-undangan kearsipan. Diperlukan seperangkat sistem kearsipan yang telah diatur dalam perundang-undangan kearsipan untuk mengimplementasikan kebijakan tersebut. Tujuannya adalah agar kepentingan negara dan hak-hak publik terlindungi. Kajian ini dilakukan dengan pendekatan Manajemen Kearsipan dan Administrasi Publik. Hasil kajian adalah beberapa masalah aspek kearsipan pada organisasi publik di Indonesia dapat diberikan solusinya dengan inovasi kebijakan kearsipan.
\end{abstract}

Kata kunci: arsip; informasi; inovasi; manajemen; administrasi publik; organisasi publik; pelayanan publik

\section{Pendahuluan}

Kebijakan kearsipan yang berlaku di Indonesia pada saat ini adalah Undang-Undang Republik Indonesia Nomor 43 Tahun 2009 tentang Kearsipan. Pemerintah berupaya menggerakkan dinamika kearsipan di Indonesia melalui kebijakan tersebut. Sosialisasi kebijakan dilakukan di seluruh organisasi publik, swasta maupun perorangan. Implementasi yang mereka lakukan merupakan upaya untuk tercapainya tujuan dari kebijakan tersebut.

Sosialisasi kebijakan kearsipan di Indonesia bukan merupakan pekerjaan yang mudah. Wilayah negara yang luas terdiri dari daratan dan perairan membentang sepanjang 3.977 mil diantara Samudera Indonesia and Samudera Pacific (Ikawati dan Setiawati, 2009), 17.508 pulau besar dan kecil dimana 6.000 diantaranya belum berpenghuni (Ikawati dan Setiawati, 2009). Selanjutnya jumlah penduduk menurut sensus tahun 2010 mencapai 237.641.326 jiwa (Badan Pusat Statistik, https://sp2010.bps.go.id/). Keadaan geografis dan demografis seperti ini menjadikan politik di negara ini sangat dinamis. 
Pada saat ini pemerintahan daerah di Indonesia mencapai 34 provinsi (Badan Pusat Statistik. https://www.bps. go.id/statictable/2014/09/05/1366/luas-daerah-dan-jumlah-pulau-menurut-provinsi2002-2016.html). Jumlah pemerintah kabupaten mencapai 415 kabupaten tidak termasuk 1 (satu) kabupaten administratif di Provinsi DKI Jakarta. Selain itu jumlah pemerintah kota mencapai 93 kota tidak termasuk 5 (lima) kota administratif di Provinsi DKI Jakarta (Direktorat Penataan Daerah, Otonomi Khusus, dan Dewan Pertimbangan Otonomi Daerah - Direktorat Jenderal Otonomi Daerah - Kementerian Dalam Negeri Republik Indonesia, 2014. http://www.bps.go.id/statictable/2014/09/05/1366/luasdaerah-dan-jumlah-pulau-menurut-provinsi-2002-2016.html).

Pada pemerintahan di bawah lagi terdapat kecamatan yang jumlahnya mencapai 7.024 kecamatan (Badan Pusat Statistik. https://www.bps.go.id/dynamictable/2015/09/07/857/jumlahkecamatan-menurut-provinsi-2004-2014.html). Sementara itu pemerintahan yang langsung bersentuhan dengan pelayanan kepada publik berada di tingkat kelurahan dan desa. Jumlah Kelurahan dan Desa di Indonesia kategori topografi lembah pada tahun 2014 mencapai 3.630 desa/kelurahan. Data yang sama untuk kategori topografi lereng mencapai 16.043 desa/kelurahan. Data yang sama untuk kategori topografi dataran mencapai 62.517 desa/kelurahan (Badan Pusat Statistik. https://www.bps.go.id/linkTableDinamis/view/id/907).

Jumlah tersebut belum termasuk lembaga negara, lembaga pemerintahan, Badan Usaha Milik Negara, Badan Usaha Milik Daerah, Badan-badan Swasta.

Merujuk pada data yang diperoleh dapat diketahui keluasan wilayah nerupakan salah satu faktor yang menghambat bagi proses transmisi kebijakan kearsipan. Ratusan juta penduduk harus dilayani hakhak publik mereka. Layanan yang diberikan sebagaimana dimaksud dalam kajian ini adalah layanan terkait dengan proses administrasi. Lembaga-lembaga publik harus mengelola arsip yang mereka ciptakan secara efektif dan efisien agar informasi berbasis arsip mudah ditemukan ketika diperlukan, serta selalu dalam kondisi yang baik. Sehubungan dengan arti penting arsip, maka arsip yang diciptakan dengan berbagai media dan corak memerlukan sumber daya pendukung agar selalu siap diakses. Kompleksitas permasalahan yang dihadapi para birokrat menghadang mereka dalam upaya implementasi kebijakan kearsipan. Kondisi ini menarik untuk diangkat sebagai permasalahan tentang apakah langkah yang harus ditempuh para birokrat agar arsip yang mereka ciptakan dapat selalu siap diakses ?

Tujuan dari kajian ini adalah agar seluruh elemen yang belum memahami arti penting arsip menjadi lebih sadar arsip. Sementara itu para implementor serta publik mengetahui, bahwa hambatan dalam implementasi kebijakan kearsipan dapat dicarikan solusinya melalui inovasi.

\section{Tinjauan Literatur}

\section{A. Inovasi}

Inovasi ditinjau dari kamus besar bahasa Indonesia online memiliki arti sebagai pemasukan atau pengenalan hal-hal yang baru. Selain itu inovasi juga dapat diartikan sebagai pembaharuan 
(https://kbbi.web.id/inovasi). Merujuk pada seluruh pengertian tersebut, maka inovasi terjadi karena sikap seseorang atau sekelompok orang yang menggerakkan kreatifitas mereka menghasilkan suatu karya baru.

Inovasi kebijakan kearsipan terkait dengan kebijakan publik. Inovasi dipahami terkait dengan perilaku, dinamis dan berkembang (Suwarno, 2011:3). Elu dan Purwanto (2010 : 3.8) mengutip pendapat para ahli perilaku yang menatap teori perilaku sebagai faktor perilaku. Faktor perilaku dalam konteks ini adalah faktor yang menyebabkan seseorang efektif sebagai pemimpin atau tidak. Robbins and Judge (2007:71) disisi lain membahas hubungan antara sikap dengan perilaku. Menurut mereka sikap mempengaruhi perilaku.

Berdasar pada kedua pemahaman tersebut maka diketahui, bahwa inovasi kearsipan adalah perilaku kreatif seseorang atau sekelompok orang yang mampu menghasilkan solusi bagi masalah-masalah yang dihadapi disaat kebijakan kearsipan diimplementasikan.

\section{B. Kebijakan Publik}

Kebijakan publik merupakan kebijakan negara yang memuat kepentingan-kepentingan publik. Para penyelenggara bekerja untuk kepentingan negara. Namun Islamy (2014:10) menyebut tidak semua penyelenggara negara memahami tugas mereka kepada publik. Kondisi ini tentu semakin tidak kondusif bila kebijakan yang hendak diimplementasikan dianggap tidak populer.

Kiwang, Pandie dan Gana (2014) melakukan penelitian terkait dampak kebijakan dengan efektifitas organisasi. Hasil penelitian mereka menunjukkan, bahwa implementasi terhadap kebijakan pemerintah daerah yang mereka teliti memberikan dampak pada peningkatan kerja pegawai.

\section{Implementasi Kebijakan Publik}

Kebijakan tidak ada maknanya bila tidak diimplementasikan. Lebih lanjut disebutkan, bahwa proses implementasi kebijakan publik melibatkan "dimensi organisasi, kepemimpinan, serta manajerial dari pemerintah" (Tachjan, 2006 : v - vi). Implementasi terhadap kebijakan publik dipengaruhi oleh faktor-faktor pendukung dan faktor-faktor penghambat. Edwards III (1980) menyebut bahwa berhasil atau tidaknya kebijakan diimplementasikan, dipengaruhi oleh aspek komunikasi, struktur birokrasi, sumber daya pendukung dan disposisi. Seluruh aspek tersebut berlangsung bersamaan disaat kebijakan tersebut diimplementasikan.

Grindle sebagaimana dikutip oleh Suwitri (2011:86 - 89) menyatakan, bahwa implementasi terhadap kebijakan publik dipengaruhi oleh variabel konten dan variabel konteks. Variabel konten terdiri dari enam unsur, yaitu: (a) pihak yang kepentingannya dipengaruhi, (b) jenis manfaat yang dapat diperoleh, (c) jangkauan perubahan yang dapat diharapkan, (d) kedudukan pengambilan keputusan, (e) pelaksana-pelaksana program, (f) sumber-sumber yang dapat disediakan. Sementara itu variabel konteks terdiri dari tiga unsur, yaitu: (a) kekuasaan, (b) karakteristik rezim dan institusi, (c) kesadaran dan sifat responsif.

Azis dan Humaizi (2013) dalam artikel penelitian mereka terkait implementasi kebijakan pusat informasi pada Dinas Komunikasi dan Informatika Pemerintah Daerah Provinsi Sumatera Utara. Aziz menyebut faktor-faktor yang mempengaruhi implementasi kebijakan adalah faktor politik, faktor 
kelembagaan, faktor perkembangan teknologi. Hasil penelitian menunjukkan dari variabel input, proses, output, out comes diperoleh hasil keberhasilan yang tidak sama.

\section{Manajemen Kearsipan}

Manajemen menurut kamus besar bahasa Indonesia online berarti penggunaan sumber daya secara efektif untuk mencapai sasaran (https://kbbi.web.id/manajemen). Sementara itu kata manajemen secara teoritis menghubungkan sub didalam sistem (Kast and Rosenzweig, 1990:7). Fungsi manajemen terdiri dari perencanaan, pengorganisasian, pengalokasian staf, pengarahan, pengawasan (Sukoco, 2007: 9-10)

Kearsipan menurut Pasal 1 butir 1 Undang-Undang Republik Indonesia Nomor 43 Tahun 2009 tentang kearsipan adalah "hal-hal yang berkenaan dengan arsip". Merujuk pada fungsi manajemen sebagaimana dikemukakan oleh Kast dan Rosenzweig, serta Sukoco, juga kamus besar bahasa Indonesia online, maka Manajemen Arsip dapat diartikan sebagai kegiatan perencanaan, pengorganisasian, pengalokasian staf, pengarahan, pengawasan di bidang kearsipan. Pemahaman ini sejalan dengan paparan Sukoco (2007:81-90)

\section{Metode Penelitian}

Metode kualitatif digunakan dalam penelitian ini. Metode ini menggunakan wawancara, dokumen, foto sebagai sumber data penelitian (Moleong, 2010:157). Pada penelitian ini digunakan dokumen, publikasai teks sebagai sumber data penelitian untuk dianalisis. Hasil analisis diharapkan menjadi solusi bagi masalah implementasi kebijakan penyelenggaraan kearsipan di I

ndonesia.

\section{Hasil dan Pembahasan}

Arsip merupakan salah satu sumber informasi. Informasi yang direkam di dalam arsip merupakan sumber informasi penting. Arti penting arsip karena digunakan untuk "decision making, documentation, response, reference, legal requirements" (Ricks and Swafford and Gow, 1992:14). Merujuk pada unsurunsur tersebut, maka kita ketahui bahwa arsip harus "dilindungi" dengan sistem kearsipan yang efektif dan efisien agar fisik maupun isi informasinya selalu siap untuk digunakan.

Penyelenggaraan kebijakan kearsipan menurut Magetsari (2008:1) dapat didekati dengan manajemen kearsipan atau ilmu kearsipan. Pada konteks implementasi kebijakan publik, maka kajian ini menggunakan pendekatan manajemen kearsipan. Pendekatan manajemen lebih tepat karena sesuai dengan aspek-aspek kebijakan yang akan diimplementasikan. Aspek-aspek yang dimaksud adalah: penetapan kebijakan, pembinaan kearsipan, pengelolaan arsip, sumber daya kearsipan.

\section{A. Inovasi dalam Implementasi Kebijakan Penyelenggaraan Kearsipan.}

Mengikuti perkembangan implementasi kebijakan kearsipan di Indonesia saat ini, diketahui bahwa para implementor mengalami hambatan dalam mengimplementasikan kebijakan tersebut. Sebagaimana telah dipaparkan pada bab tinjauan literatur diketahui, bahwa inovasi dalam implementasi kebijakan kearsipan dapat berpijak pada aspek-aspek yang diatur dalam Undang-Undang Republik Inonesia Nomor 
43 Tahun 2009 tentang Kearsipan, serta Peraturan Pemerintah Republik Indonesia Nomor 28 Tahun 2012 tentang Pelaksanaan Undang-Undang Republik Indonesia Nomor 43 Tahun 2009 tentang Kearsipan.

\section{B. Aspek Penetapan Kebijakan}

Penetapan kebijakan kearsipan ditetapkan oleh pimpinan organisasi masing-masing. Kebijakan tersebut disusun dengan merujuk pada perundang-undangan kearsipan. Sejarah implementasi kebijakan kearsipan di Indonesia diwarnai dengan dinamika perundang-undanganan kearsipan. Sebagaimana diketahui, bahwa menurut Pasal 7 ayat (1) Undang-Undang Republik Indonesia Nomor 12 Tahun 2011 tentang Pembentukan Peraturan Perundang-undangan diketahui, bahwa struktur perundang-undangan setelah undang-undang adalah peraturan pemerintah. Pada Pasal 12 undang-undang yang sama mengatur, bahwa peraturan pemerintah merupakan ketentuan pelaksanaan terhadap suatu undang-undang. Ketentuan selanjutnya adalah peraturan pemerintah menjadi landasan bagi penyusunan perundang-undangan dibawahnya. Dengan demikian para implementor harus berpikir kreatif agar fisik maupun isi informasi yang direkam didalam arsip dapat diselamatkan walau belum ada penetapan - penetapan kebijakan pimpinan organisasi terkait penyelenggaraan kearsipan.

Contoh kasus terkait penetapan kebijakan kearsipan adalah implementor kebijakan harus menyusun penetapan kebijakan, tetapi Peraturan Kepala Arsip Nasional Republik Indonesia (PERKA ANRI) terkait belum terbit. Undang-Undang Republik Indonesia Nomor 43 Tahun 2009 tentang Kearsipan diantaranya mengatur tentang Pengelolaan Arsip Dinamis dan Pengelolaan Arsip Statis. Pasal 40 ayat (4) mengatur bahwa dalam penyelenggaraan kearsipan dinamis diperlukan tata naskah dinas, klasifikasi arsip, jadwal retensi arsip, sistem klasifikasi keamanan dan akses arsip. Sebelum peraturan pemerintah sebagai pelaksana undang-undang ini diundangkan, maka Peraturan Kepala Arsip Nasional Republik Indonesia (PERKA ANRI) tentang pedoman penyusunan klasifikasi arsip serta PERKA ANRI tentang pedoman sistem klasifikasi keamanan dan akses arsip (SKKAA) diterbitkan pada tahun 2011. Sementara itu PERKA ANRI tentang pedoman tata naskah dinas diterbitkan pada tahun 2014. Adapun PERKA ANRI tentang tata cara penyusunan pedoman retensi arsip diterbitkan pada tahun 2015.

Mengingat arti penting pedoman-pedoman kearsipan bagi proses administrasi organisasi, maka sejumlah organisasi telah menciptakan pedoman tata naskah dinas tanpa tuntunan pedoman dari ANRI. Contoh terhadap kasus tersebut adalah diterbitkannya Peraturan Rektor Universitas Diponegoro Semarang Nomor13 Tahun 2013 tentang Pedoman Tata Naskah Dinas di Lingkungan Universitas Diponegoro. Universitas Negeri Semarang juga menerbitkan Peraturan Rektor Universitas Negeri Semarang Nomor 22 Tahun 2013 tentang Pedoman Tata Naskah Dinas di Lingkungan Universitas Negeri Semarang. Institusi pendidikan tinggi ini berinovasi agar organisasi tetap berlangsung.

PERKA ANRI Nomor 2 Tahun 2014 tentang Pedoman Tata Naskah Dinas diterbitkan pada tahun 2014. Diketahui organisasi-organisasi yang telah menyusun pedoman tersebut melakukan revisi disesuaikan dengan PERKA ANRI terkait. Universitas Diponegoro kini telah mengoperasikan penggunaan Peraturan Rektor Universitas Diponegoro Nomor 12 Tahun 2016 tentang Tata Naskah Dinas Universitas Diponegoro. Sementara itu Universitas Negeri Semarang juga telah menggunakan Peraturan 
Rektor Universitas Negeri Semarang Nomor 28 Tahun 2016 tentang Pedoman Tata Naskah Dinas di Lingkungan Universitas Negeri Semarang. Merujuk pada bagian pertimbangan pada kedua peraturan rektor tersebut diketahui, bahwa kedua perguruan tinggi negeri itu menerbitkan peraturan rektor tentang tata naskah dinas mendasarkan diri pada Peraturan Menteri Riset, Teknologi dan Pendidikan Tinggi Republik Indonesia Nomor 51 Tahun 2015 tentang Tata Naskah Dinas di Lingkungan Kementerian Riset, Teknologi dan Pendidikan Tinggi.

PERKA ANRI lainnya yang menjadi pedoman pengelolaan arsip dinamis adalah pedoman klasifikasi arsip terbit pada tahun 2011, pedoman jadwal retensi arsip untuk berbagai sektor diterbitkan pada tahun 2015, pedoman sistem klasifikasi keamanan dan akses arsip terbit pada tahun 2011. Sementara itu Arsip Universitas Gadjah Mada (Arsip UGM) selaku Lembaga Kearsipan Universitas Gadjah Mada dibentuk pada tahun 2004. Kebijakan kearsipan yang berlaku pada saat itu adalah Undang-Undang Republik Indonesia Nomor 7 Tahun 1971 tentang Ketentuan-Ketentuan Pokok Kearsipan. Sehubungan dengan kebutuhan pedoman bagi penyelenggaraan kearsipan, maka lembaga kearsipan ini kemudian berinovasi dengan menyusun dan mengoperasikan Peraturan Rektor Universitas Gadjah Mada Nomor 408/P/SK/HT/2009 tentang Jadwal Retensi Arsip dan Pedoman Penyusutan Arsip di Lingfkungan Universitas Gadjah Mada. Selain itu UGM juga menerbitkan Panduan Ringkas Tata Kelola Arsip Inaktif di Lingkungan Universitas Gadjah Mada. Pedoman ini nampak ditandai dengan tahun 2011.

\section{Pembinaan Kearsipan}

Pembinaan kearsipan merupakan salah satu kegiatan kearsipan yang seharusnya juga ditetapkan oleh pimpinan organisasi. Pada prakteknya tiap organisasi kearsipan melakukan pembinaan sesuai dengan kebijakan organisasi masing-masing. Contoh kasus bagi kajian ini adalah pembinaan kearsipan di lingkungan Universitas Indonesia (UI) dilakukan dengan pengajuan pembinaan oleh masing-masing pengelola Unit Kearsipan II kepada Arsip UI, Permohonan pembinaan diajukan dengan mengisi formulir yang telah disediakan di website Arsip UI. (arsip.ui.ac.id dan http://law.ui.ac.id/v3/pelatihanpengelolaan-arsip-dinamis-di-lingkungan-fhui/).

Pembinaan kearsipan di lingkungan Universitas Gadjah Mada dilakukan tidak hanya dalam hal pengelolaan arsip, tetapi juga pengembangan sumber daya manusia kearsipan. Pengembangan sumber daya manusia kearsipan di lingkungan Arsip UGM diantaranya adalah dengan memberikan kesempatan kepada mereka untuk melanjutkan studi, mengikuti bimbingan teknis yang diselenggarakan oleh ANRI, benchmarking, mengikuti kompetisi, serta pembinaan pengurusan kenaikan pangkat dan jabatan. Sementara itu pembinaan kepada Arsiparis maupun pengelola arsip di lingkungan Unit Kearsipan II dalam bentuk pelatihan kearsipan di lingkungan internal UGM, benchmarking, serta koordinasi antara Unit Kearsipan II dengan Arsip UGM dengan membentuk Forum Kearsipan Universitas Gadjah Mada atau Forsipagama (arsip.ugm.ac.id dan https://ugm.ac.id/en/berita/8208-pelantikan.forsipagama.dan. penghargaan.petugas.kearsipan.meriahkan.peringatan.dies.ix.arsip.ugm), Komunikasi antara Arsip UGM dengan para Arsiparis dan pengelola arsip di lingkungan UGM menjadi lebih intens melalui forum tersebut. 


\section{Pengelolaan Arsip Dinamis}

Penyelenggaraan kearsipan wajib dilaksanakan khususnya pada organisasi publik dan organisasi swasta yang mendapatkan pekerjaan dengan biaya dari Anggaran Pendapatan Belanja Negara (APBN) maupun Anggaran Pendapatan Belanja Daerah (APBD). Pada bagian pendahuluan telah dipaparkan tentang kondisi geografis, demografis, topografis negara Indonesia sehingga semakin jauh dari pusat pemerintahan, semakin sulit dipantau implementasinya. Pasal 8 ayat (1) Mengikuti undang-undang bahwa ANRI sebagai pembina kearsipan nasional mencakup seluruh strata dalam pemerintahan, maka peneliti meyakini semakin luas wilayah implementor, semakin sulit kebijakan diimplementasikan. Edwards III (1980:134) berpendapat bahwa semakin panjang strata birokrasi, maka proses transmisi kebijakan yang dilakukan oleh pemerintah pusat ke para implementor yang berada pada struktur birokrasi paling bawah juga semakin sulit. Gambaran kondisi yang dikhawatirkan Edwards III nampak pada aturan Ayat (1) Pasal 8 Undang-Undang Republik Indonesia Nomor 43 Tahun 2009 tentang Kearsipan, bahwa:

"Pembinaan kearsipan nasional sebagaimana dimaksud dalam Pasal 6 ayat (5) dilaksanakan oleh lembaga kearsipan nasional terhadap pencipta arsip tingkat pusat dan daerah, lembaga kearsipan daerah provinsi, lembaga kearsipan daerah kabupaten/kota, dan lembaga kearsipan perguruan tinggi"

Pedoman tata naskah dinas dipilih oleh peneliti sebagai sampel untuk dianalisis. Peneliti melakukan survei melalui internet dan menemukan masih ada kementerian, pemerintah daerah provinsi, pemerintah daerah kabupaten/kota, perguruan tinggi negeri yang belum memiliki Pedoman-pedoman bagi pengelolaan arsip dinamis dan pengelolaan arsip statis. Peneliti melakukan kajian terhadap pedoman tata naskah dinas pada lima kementerian, lima pemerintah daerah provinsi, lima pemerintah daerah kabupaten/kota dan lima perguruan tinggi. Seluruh unit analisis pada masing-masing kelompok disebut sebagai "A", "B", "C", "D", "E".

Undang-Undang Republik Indonesia Nomor 12 Tahun 2011 tentang Pembentukan Peraturan Perundang-undangan merupakan dasar analisis terhadap struktur perundang-undangan yang digunakan sebagai pertimbangan penetapan kebijakan. Sementara itu ANRI menurut Bab VI Pasal 25 Ayat 2 Undang-Undang Republik Indonesia Nomor 39 Tahun 2008, serta Pasal 1 butir 2 Peraturan Presiden Republik Indonesia Nomor 4 Tahun 2013 tentang Perubahan Kedelapan atas Keputusan Presiden Nomor 110 Tahun 2001 tentang Unit Organisasi dan Tugas Eselon I Lembaga Pemerintah Non Kementerian merupakan Lembaga Pemerintah Non Kementerian (LPNK) dengan tugas dan fungsi di bidang kearsipan. Mengingat ANRI merupakan pembina kearsipan nasional, maka Bagian Pertimbangan Peraturan ANRI Nomor 7 Tahun 2018 tentang Tata Naskah Dinas di Lingkungan Arsip Nasional Republik Indonesia dijadikan sebagai dasar analisis terhadap Peraturan Menteri, Peraturan Gubernur, Peraturan Bupati/Walikota, Peraturan Rektor yang terpilih sebagai unit analisis penelitian ini.

Undang-Undang Republik Indonesia Nomor 43 Tahun 2009 tentang Kearsipan, Peraturan Pemerintah Republik Indonesia Nomor 28 Tahun 2012 tentang Pelaksanaan Undang-Undang Republik Indonesia Nomor 43 Tahun 2009 tentang Kearsipan, Peraturan Kepala Arsip Nasional Nomor 2 Tahun 
2014 tentang Pedoman Tata Naskah Dinas merupakan dasar pertimbangan bagi penetapan Peraturan Kepala Arsip Nasional Republik Indonesia tentang Tata Naskah Dinas di ingkungan Arsip Nasional Republik Indonesia. Perundang-undangan terkait tata naskah dinas yang digunakan oleh masing-masing organisasi sebagai pertimbangan dalam penetapan tata naskah dinas disandingkan dengan bagian pertimbangan pada Peraturan Kepala Arsip Nasional Republik Indonesia Nomor 7 Tahun 2018 tentang Tata Naskah Dinas di Lingkungan Arsip Nasional Republik Indonesia. Sementara itu Peraturan Menteri Pendayagunaan Aparatur Negara dan Reformasi Birokrasi Republik Indonesia Nomor 80 Tahun 2012 tentang Pedoman Tata Naskah Dinas Instansi Pemerintah ditampilkan pada tabel 1 untuk mengetahui kementerian yang masih menggunakan peraturan tersebut. Hasil analisis yang diperoleh nampak pada tabel 1 sampai dengan tabel 4 berikut ini:

Tabel 1. Pedoman Tata Naskah Dinas di Lingkungan Kementerian

\begin{tabular}{|l|l|l|l|l|}
\hline $\begin{array}{l}\text { Kementerian } \\
\text { (Tahun } \\
\text { penetapan } \\
\text { peraturan tata } \\
\text { naskah dinas) }\end{array}$ & $\begin{array}{l}\text { UU RI No.43 Tahun } \\
\text { tentang Kearsipan }\end{array}$ & $\begin{array}{l}\text { PP RI No.28 Tahun } \\
2012 \text { tentang } \\
\text { Pelaksanaan UU RI } \\
\text { No.43 Tahun 2009 }\end{array}$ & $\begin{array}{l}\text { Perka ANRI No.2 } \\
\text { Tahun 2014 tentang } \\
\text { Pedoman Tata Naskah } \\
\text { Dinas }\end{array}$ & $\begin{array}{l}\text { Pernenpan dan RB } \\
\text { No. 80 Tahun 2012 } \\
\text { tentang Pedoman } \\
\text { Tata Naskah Dinas } \\
\text { Instansi Pemerintah }\end{array}$ \\
\hline ANRI (2018) & Ada & Ada & Ada & Tidak ada \\
\hline "A" (2016) & Tidak ada & Tidak ada & Tidak ada & Tidak ada \\
\hline "B" (2010) & Ada & Tidak ada & Tidak ada & Tidak ada \\
\hline "C" (2015) & Ada & Ada & Tidak ada & Ada \\
\hline "D" (2016) & Tidak ada & Tidak ada & Ada & Tidak ada \\
\hline "E" (2016) & Ada & Ada & Tidak ada & Tidak ada \\
\hline
\end{tabular}

Tabel 1 menunjukkan tim penyusun peraturan pada lima kementerian tidak memiliki kesamaan terhadap perundang-undangan yang digunakan sebagai dasar pertimbangan hukum dalam penyusunan peraturan tata naskah dinas. Selain itu juga dketahui, bahwa mereka belum melakukan update terhadap penetapan kebijakan tata naskah dinas.

Tabel 2. Pedoman Tata Naskah Dinas di Lingkungan Pemerintah Provinsi

\begin{tabular}{|l|l|l|l|l|}
\hline $\begin{array}{l}\text { Provinsi } \\
\text { (Tahun } \\
\text { penetapan } \\
\text { peraturan tata } \\
\text { naskah dinas) }\end{array}$ & $\begin{array}{l}\text { UU RI No.43 Tahun } \\
\text { tentang Kearsipan }\end{array}$ & $\begin{array}{l}\text { PP RI No.28 Tahun } \\
2012 \text { tentang } \\
\text { Pelaksanaan UU RI } \\
\text { No.43 Tahun 2009 }\end{array}$ & $\begin{array}{l}\text { Perka ANRI No.2 } \\
\text { Tahun 2014 tentang } \\
\text { Pedoman Tata Naskah } \\
\text { Dinas }\end{array}$ & $\begin{array}{l}\text { Permendagri No.42 } \\
\text { Tahun 2016 tentang } \\
\text { Tata Naskah Dinas } \\
\text { di Lingkungan } \\
\text { Kementerian Dalam } \\
\text { Negeri }\end{array}$ \\
\hline ANRI & Ada & Ada & Ada & Tidak ada \\
\hline "A" (2012) & Tidak ada & Tidak ada & Tidak ada & Tidak ada \\
\hline "B" (2010) & Tidak ada & Tidak ada & Tidak ada & Tidak ada \\
\hline "C" (2016) & Tidak ada & Tidak ada & Tidak ada & Tidak ada \\
\hline "D" (2014) & Ada & Tidak ada & Tidak ada & Tidak ada \\
\hline "E" (2012) & Tidak ada & Tidak ada & Tidak ada & Tidak ada \\
\hline
\end{tabular}


Analisis terhadap tabel 2 menunjukkan ANRI tidak menggunakan Permendagri No.42 Tahun 2016 tentang Tata Naskah Dinas di Lingkungan Kementerian Dalam Negeri karena ANRIadaahlpebmina kearsipan nasional. Selanjutnya diketahui bahwa dasar pertimbangan hukum dalam penyusunan peraturan tata naskah dinas hampir sama sekali tidak digunakan. Merujuk pada angka tahun penetapan tata naskah dinas diketahui, bahwa mereka belum melakukan update terhadap penetapan kebijakan tata naskah dinas.

Tabel 3. Pedoman Tata Naskah Dinas di Lingkungan Pemerintah Kabupaten/Kota

\begin{tabular}{|l|l|l|l|l|}
\hline $\begin{array}{l}\text { Pemerintah } \\
\text { Kabupaten/Kota }\end{array}$ & $\begin{array}{l}\text { UU RI No.43 Tahun } \\
\text { 2009 } \\
\text { tentang Kearsipan }\end{array}$ & $\begin{array}{l}\text { PP RI No.28 Tahun } \\
2012 \text { tentang } \\
\text { Pelaksanaan UU RI } \\
\text { No.43 Tahun 2009 }\end{array}$ & $\begin{array}{l}\text { Perka ANRI No.2 } \\
\text { Tahun 2014 tentang } \\
\text { Pedoman Tata Naskah } \\
\text { Dinas }\end{array}$ & $\begin{array}{l}\text { Permendagri No.42 } \\
\text { Tahun 2016 tentang } \\
\text { Tata Naskah Dinas } \\
\text { di Lingkungan } \\
\text { Kementerian Dalam } \\
\text { Negeri }\end{array}$ \\
\hline ANRI & Ada & Ada & Ada & Tidak ada \\
\hline "A" (2012) & Ada & Tidak ada & Tidak ada & Tidak ada \\
\hline "B" (2011) & Tidak ada & Tidak ada & Tidak ada & Tidak ada \\
\hline "C" (2013) & Ada & Tidak ada & Tidak ada & Tidak ada \\
\hline "D" (2015) & Tidak ada & Tidak ada & Ada & Tidak ada \\
\hline "E" (2012) & Tidak ada & Tidak ada & Tidak ada & Tidak ada \\
\hline
\end{tabular}

Analisis terhadap tabel 3 menunjukkan tim penyusun peraturan pada lima pemerintah kabupaten/kota hampir semuanya memiliki kesamaan, yaitu tiga dasar pertimbangan hukum dalam penyusunan peraturan tata naskah dinas hampir sama sekali tidak digunakan. Mengacu pada tahun penetapan tata naskah dinas diketahui, bahwa mereka belum melakukan update terhadap penetapan kebijakan tata naskah dinas.

Tabel 4. Pedoman Tata Naskah Dinas di Lingkungan Perguruan Tinggi

\begin{tabular}{|l|l|l|l|l|l|}
\hline $\begin{array}{l}\text { Perguruan } \\
\text { Tinggi }\end{array}$ & $\begin{array}{l}\text { UU RI No.43 Tahun } \\
2009 \\
\text { tentang Kearsipan }\end{array}$ & $\begin{array}{l}\text { PP RI No.28 Tahun } \\
2012 \text { tentang } \\
\text { Pelaksanaan UU RI } \\
\text { No.43 Tahun 2009 }\end{array}$ & $\begin{array}{l}\text { Perka ANRI 2014 tentang } \\
\text { Tahun } \\
\text { Pedoman Tata Naskah } \\
\text { Dinas }\end{array}$ & $\begin{array}{l}\text { Permenristekdikti } \\
\text { No.51 Tahun 2015 } \\
\text { tentang Tata Naskah } \\
\text { Dinas di Lingkungan } \\
\text { Kementerian Riset, } \\
\text { Teknologi, dan } \\
\text { dendidikan Tinggi }\end{array}$ \\
\hline ANRI & Ada & Ada & Ada & - \\
\hline "A" & Tidak ada & Tidak ada & Tidak ada & Tidak Ada \\
\hline "B" & Tidak ada & Tidak ada & Ada & Ada \\
\hline "C" & Ada & Ada & Tidak ada & Ada \\
\hline "D" & Tidak ada & Tidak ada & Tidak ada & Ada \\
\hline "E" & Tidak ada & Tidak ada & Tidak ada & Ada \\
\hline
\end{tabular}


Analisis terhadap tabel 4 menunjukkan tim penyusun peraturan pada lima perguruan tinggi negeri hampir semuanya memiliki kesamaan, yaitu tiga dasar pertimbangan hukum dalam penyusunan peraturan tata naskah dinas hampir sama sekali tidak digunakan. Nampak, bahwa empat perguruan tinggi menggunakan Permenristekdikti No.51 Tahun 2015 tentang Tata Naskah Dinas di Lingkungan Kementerian Riset, Teknologi, dan Pendidikan Tinggi.

Dari seluruh tabel 1 sampai dengan tabel 4 diketahui, bahwa pada era Undang-Undang Republik Indonesia Nomor 43 Tahun 2009 tentang Kearsipan diketahui, bahwa masih ditemukan organisasi pemerintah yang belum melakukan update terhadap penetapan kebijakan tentang tata naskah dinas. Kita ketahui, bahwa tata naskah dinas merupakan pilar pertama dalam pengelolaan arsip dinamis. Bila pilar pertama kurang diperhatikan, maka penetapan kebijakan pada ketiga pilar yang lain serta penetapan kebijakan arsip statis juga menjadi pertanyaan.

Contoh kasus inovasi penetapan kebijakan kearsipan diketahui pernah dilakukan oleh Arsip Universitas Gadjah Mada (Arsip UGM). Arsip UGM dibentuk pada tahun 2004 melalui Surat Keputusan Rektor UGM Nomor 259/P/SK/HT/2004 tentang Organisasi dan Rincian Tugas Kantor Pimpinan Universitas, Lembaga, Direktorat, Biro, dan Unit Kerja di Lingkungan Universitas Gadjah Mada. Keberadaan lembaga kearsipan perguruan tinggi ini dibentuk pada era Undang-Undang Republik Indonesia Nomor 7 Tahun 1971 tentang Ketentuan-Ketentuan Pokok Kearsipan. Diketahui undangundang ini belum mengatur secara eksplisit tentang lembaga kearsipan perguruan tinggi.

Arsip UGM melengkapi organisasi kearsipan ini dengan penetapan-penetapan kebijakan sebagai pendukung dalam pelaksanan tugasnya. Penetapan kebijakan yang dimaksud adalah Peraturan Rektor Universitas Gadjah Mada Nomor 408/SK/HT/2009 tentang Jadwal Retensi Arsip dan Pedoman Penyusutan Arsip di Lingkungan Universitas Gadjah Mada.Keberadaannya ditetapkan pada tanggal 26 Oktober 2009. Penetapan kebijakan ini didasarkan pada Undang-Undang Republik Indonesia Nomor7 Tahun 1971 tentang Ketentuan-Ketentuan Pokok Kearsipan, serta Peraturan Pemerintah Republik Indonesia Nomor 34 Tahun 1979 tentang Penyusutan Arsip. Sehubungan dengan Undang-Undang Republik Indonesia Nomor 7 Tahun 1971 tentang Ketentuan-Ketentuan Pokok Kearsipan belum mengatur secara eksplisit tentang lembaga kearsipan perguruan tinggi serta berbagai pedoman teknik pengelolaan arsip, maka Arsip UGM melakukan inovasi terhadap kebutuhan pedoman tersebut.

Pedoman pengelolaan arsip diperlukan sebagai panduan bagi para Arsiparis maupun pengelola arsip dalam menjalankan tugasnya. Perundang-undangan kearsipan belum mengatur ketentuan tersebut secara khusus. Sehubungan dengan kebutuhan pedoman bagi pengeolaan arsip dinamis, maka Arsip UGM menetapkan Panduan Ringkas Tata Kelola Arsip Inaktif di Lingkungan Universitas Gadjah Mada ditetapkan pada tahun 2011 sebagai bagian dari pedoman pengelolaan arsip dinamis.

\section{E. Pengelolaan Arsip Dinamis}

Pengelolaan arsip statis diatur pada Bab IV Pasal 40 sampai dengan Pasal 58 Undang-Undang Republik Indonesia Nomor 43 Tahun 2009 tentang Kearsipan. Inovasi pada aspek pengelolaan arsip dinamis merupakan suatu keniscayaan, mengingat berbagai faktor penghambat terjadi pada implementasi 
kebijakan kearsipan. Sehubungan dengan hambatan yang terjadi, maka Arsiparis maupun pengelola arsip di Unit Pengolah hingga lembaga kearsipan dituntut memiliki kreatifitas untuk berinovasi. Inovasi pada umumnya terkait dengan sistem pencatatan surat maupun dokumen lain secara elektronik.

ANRI telah mendesain aplikasi Sistem Informasi Kearsipan Dinamis (SIKD). Namun, era eGovernement lebih dulu hadir dan diaplikasikan oleh organisasi-organisasi publik maupun swasta sebelum aplikasi SIKD disosialisasikan. Mereka yang sudah mapan dengan aplikasi yang ada kesulitan untuk beradaptasi dengan aplikasi yang baru.

Bagi organisasi yang memiliki pegawai yang kreatif memilih membuat aplikasi sederhana untuk memenuhi kebutuhan layanan informasi berbasis arsip. Situasi ini menyebabkan sistem informasi di organisasi tersebut mengalami dikotomi. Input data yang dilakukan oleh admin di unit pencipta arsip tidak dapat dilanjutkan ke unit kearsipan II karena sistemnya tidak terintegrasi. Pada tahap selanjutnya, data yang sama dan telah diinput ulang oleh Arsiparis di Unit Kearsipan II pencipta arsip secara elektronik tidak dapat digunakan di Lembaga Kearsipan organisasi tersebut.

Organisasi yang memiliki kemampuan pendanaan pada umumnya menggunakan jasa pihak ketiga untuk mendesain aplikasi terintegrasi bagi organisasi mereka. Berbagai terobosan dilakukan oleh berbagai organisasi publik. Terobosan dilakukan agar layanan kepada publik menjadi lebih efektif dan efisien. Contoh yang termasuk pada kasus ini adalah inovasi samsat corner di Kota Malang (Fitranti dan Rochmah dan Hanafi, J. Administrasi Publik, Vol.2, No.2:374 - 380). Kementerian Pendidikan dan Kebudayaan juga menciptakan aplikasi Sistem Pengelolaan Arsip dan Dokumen (SPAD) pada tahun 2017. Aplikasi ini merupakan hasil adopsi terhadap Sistem Informasi Kearsipan Nasional (SIKN), Jaringan Informasi Kearsipan Nasional (JIKN), Sistem Informasi Kearsipan Dinamis (SIKD) Seluruh aplikasi tersebut berasal dari Arsip Nasional Republik Indonesia (ANRI). Merujuk pada failitas dan proses pengoperasian aplikasi SPAD, nampaknyha aplikasi tersebut ditujukan untuk manajemen arsip dinamis (https://biroumum.kemdikbud.go.id/web/files/SPAD_Operator_Unit_Satker.pdf)

\section{F. Pengelolaan arsip statis}

Pengelolaan arsip statis diatur pada Bab V Pasal 59 sampai dengan Pasal 67 Undang-Undang Republik Indonesia Nomor 43 Tahun 2009 tentang Kearsipan. Aturan yang ditetapkan mencakup akuisisi arsip statis, pengolahan arsip statis, preservasi arsip statis, akses arsip statis. Pengelolaan terhadap arsip ini pada umumnya disebut sebagai manajemen arsip statis. Implementasi terhadap arsip statis memerlukan seperangkat pedoman pengelolaan arsip statis, sumber daya pendukung. Inovasi yang dilakukan dalam pengelolaan arsip masih berkisar pada sistem informasi kearsipan. Faktanya yang terjadi sama dengan pengelolaan arsip dinamis.

Arsip Universitas Gadjah Mada merupakan salah satu lembaga kearsipan yang berinovasi dalam penciptaan dan penggunaan sistem informasi kearsipan statis (http://arsip.ugm.ac.id.siks). Arsip UGM memaksimalkan aplikasi tersebut agar para pengguna khazanah arsip yang dikelola di Arsip UGM dapat mengakses arsip tanpa hadir secara fisik ke ruang layanan arsip di Arsip UGM. 


\section{G. Sumber Daya Pendukung Kearsipan}

Sumber daya pendukung merupakan aspek penting dalam implementasi kebijakan. Menurut EdwardsIII (1980:53) keberadaan sumberdaya merupakan alasan kebijakan dapat diimplementasikan secara efektif. Sumrahyadi (2016) berpendapat, bahwa unsur sistem, sumber daya manusia kearsipan, kelembagaan, sarana prasarana sebagai unsur yangdominan diperlukan dalam penyelenggaraan kearsipan.

\section{H. Sumber Daya Manusia Kearsipan}

Unsur sumber daya yang paling esensial dari implementasi kebijakan sejatinya terletak pada unsur sumber daya manusia (Edwards III, 1980 : 54). Pada prakteknya teori ini sesuai diterapkan dalam bidang kearsipan (Suhana, 2016: 47). Ketentuan tentang sumber daya manusia kearsipan dalam Pasal 30 Undang-Undang Republik Indonesia Nomor 43 Tahun 2009 tentang Kearsipan. Seentara itu ketentuan tentang sumber daya manusia kearsipan dengan status pegawai negeri sipil saat ini diatur dalam Peraturan Menteri Pendayagunaan Aparatur Negara dan Reformasi Birokrasi Republik Indonesia Nomor 48 Tahun 2014 tentang Jabatan Fungsional Arsiparis. Kebijakan tersebut diubah dengan Peraturan Menteri Pendayagunaan Aparatur Negara dan Reformasi Birokrasi Republik Indonesia Nomor 13 Tahun 2016 tentang Perubahan atas Peraturan Menteri Pendayagunaan Aparatur Negara dan Reformasi Birokrasi Republik Indonesia Nomor 48 Tahun 2014 tentang Jabatan Fungsional Arsiparis. Petunjuk Teknis Pelaksanaan Pembinaan Jabatan Fungsional Arsiparis diatur dalam Peraturan Kepala Badan Kepegawaian Negara Nomor 24 Tahun 2016.

Pengembangan sumber daya manusia kearsipan dalam konteks pengadaannya bukan merupakan kebijakan yang mudah dilakukan. Khususnya Negara Indonesia merupakan negara yang sulit dalam pengadaan sumber daya manusia kearsipan. Penyebabnya adalah karena lembaga pendidikan tinggi yang menyelenggarakan program studi kelanjutan dari Program Studi Diploma III Kearsipan belum ada. Oleh sebab itu pengembangan sumber daya manusia kearsipan dilakukan dengan impassing/penyesuaian. Selain masalah ketiadaan program studi setingkat Diploma IV dan seterusnya, faktor pendanaan juga merupakan faktor yang menghambat pengebangan sumber daya manusia kearsipan.

Ketiadaan sumber daya manusia kearsipan akan memberikan dampak yang luar biasa bagi organisasi pencipta arsip. Arsip akan menumpuk di Unit Pencipta arsip karena tidak pernah disusutkan. Arsip sulit ditemubalik karena tidak dilakukan pencatatan sesuai sistem kearsipan. Ketiadaan sistem kearsipan tidak memberikan dampak apapun bila disediakan ruang arsip (Suhana, 2016:48)

Berbagai persoalan hambatan dalam pengembangan dalam konteks pengadaan suber daya manusia harus diberikan solusinya agar masalah-masalah sebagai damapak dari masalah tersebut tidak terjadi. Dalam perundang-undangan kearsipan memungkinkan seseorang pegawai negeri sipil non kompetensi kearsipan yang hendak menjadi fungsional Arsiparis dapat menempuh jalur penyesuaian. Namun bila tidak ada kandidat tersebut, maka pada umumnya organisasi tersebut menerima pegawai secara mandiri sebagai pengelola arsip.

Universitas Gadjah Mada (UGM) memiliki sejarah tentang sumber daya manusia kearsipan yang patut dijadikan sebagai contoh tentang kasus ini. Data pada tahun 2013 menunjukkan, bahwa pada tahun 
tersebut baru sembilan unit kerja di lingkungan UGM telah memiliki 20 Arsiparis dengan berbagai latar belakang pendidikan. Delapan diantaranya adalah Arsiparis di lingkungan Arsip UGM (Kurniatun, 2013). Pada tahun 2015 sebaran SDM Kearsipan telah menyebar di 14 unit kerja di lingkungan Kantor Pusat UGM dan 20 unit kerja dilingkungan Fakultas termasuk Magister Administrasi Publik. Lingkungan Kantor Pusat UGM memiliki delapan Arsiparis dan delapanbelas Pengelola Arsip. Sementara itu lingkungan Fakultas dan MAP di lingkungan UGM memiliki 10 Arsiparis dan 21 Pengelola Arsip (Wawancara dengan Kepala Bidang Database Arsip UGM pada tanggal 11 Agustus 2015). Jumlah ini masih belum mencukupi kebutuhan Arsiparis maupun Pengelola Arsip bagi lingkungan UGM terlebih lagi lingkungan Arsip UGM. Dengan demikian perguruan tinggi ini masih harus meningkatkan kuantitas sumber daya manusia kearsipannya.

Dari uraian pada alinea di atas diketahui, bagaimana inovasi terhadap kebijakan pengadaan sumber daya manusia kearsipan. Bila bersikeras menunggu pengadaan Arsiparis, maka dikhawatirkan arsip semakin tidak terkelola secara sistematis atau bahkan tidak tersentuh sama sekali.

\section{Prasarana dan sarana}

Prasarana dan sarana merupakan pendukung dalam suatu kegiatan (Edward III, 1980: 77). Demikian pula dengan implementasi kebijakan kearsipan juga membutuhkan fasilitas tersebut, seperti depot arsip statis, ruang penyimpan arsip inaktif, perlengkapan kearsipan elektronik maupun konvensional.

Pengadaan prasarana dan sarana kearsipan bukan merupakan suatu hal yang mudah untuk diwujudkan. Masalah yang dihadapi oleh penyelenggaran kearsipan tidak hanya terjadi di Indonesia. Wawancara yang dilakukan oleh peneliti dengan William Joseph Maher sebagai Arsiparis Illinois University melalui email sejak akhir Maret hingga akhir Agustus 2015 menunjukkan situasi yang sama. Simpulan yang ditarik oleh peneliti dari hasil wawancara tersebut adalah Arsiparis dan Pengelola Arsip harus memiliki jiwa kreatif. Dengan jiwa tersebut mereka akan mampu berinovasi untuk mendapatkan solusi bagi setiap tantangan yang dihadapi dalam melaksanakan tugas.

Pejabat Dekan Fakultas Peternakan dan Fakultas Kedokteran Gigi UGM periode 2008 - 2012 merupakan contoh pimpinan organisasi yang telah memiliki kesadaran terhadap arti penting arsip. Arsiparis yang dimiliki diberikan tugas dan fungsi sebagai Arsiparis.

Ruang penyimpan arsip inaktif diperlukan bagi setiap unit kerja. Mengingat arti penting fasilitas tersebut, diketahui bahwa Fakultas Peternakan UGM pada tahun 2012 memanfaatkan ruang yang sudah ada untuk ruang pengolah meskipun masih menyatu dengan ruang penyimpan arsip (Buletin Khazanah, Juli 2012, 5 (2): 15-27). Sementara itu Fakultas Kedokteran Gigi juga memanfaatkan ruangan yang sudah ada. Tetapi, ruang pengolah arsip sudah terpisah dari ruang penyimpan arsip (Buletin Khazanah, November 2012, 5 (3): 44-52.

Arsip UGM sebagai pembina kearsipan memiliki tugas dan fungsi diantaranya melakukan pembinaan kearsipan di lingkungan UGM. Mengingat sejarah kelahirannya sebelum Undang-Undang Republik Indonesia Nomor 43 Tahun 2009 tentang Kearsipan diundangkan, maka unit kerja ini 
melakukan berbagai karya inovasi. Diantaranya adalah memanfaatkan pipa paralon sebagai tempat penyimpan arsip kartografi statis, pembuatan Kode Simpan Arsip Statis Kartografi, pembuatan aplikasi berbasis web sebagai alat bantu penelusuran (finding aids) koleksi arsip statis dengan alamat http://arsip.ugm.ac.id/siks/, Daftar Khazanah Arsip (DKA) Kartografi, Kearsitekturan dan Gambar Teknik, Daftar Klasifikasi Masalah Arsip Statis Kartografi di Arsip UGM (Handayani, http://anitanet. staff.ipb.ac.id/arsiparis/kode-arsip-statis-kartografi-ugm/). Inovasi kearsipan yang dilakukan oleh Arsip UGM mampu mengantar lembaga kearsipan ini meraih akreditasi nyaris dengan nilai excellent dari ANRI pada 23 Desember 2015 (Gloria/Humas UGM, 2015. https://ugm.ac.id/id/berita/10953arsip.ugm.raih.akreditasi.tertinggi.dari.anri)

\section{J. Pendanaan}

Aspek pendanaan kearsipan diatur dalam Pasal 38 dan Pasal 39 Undang-Undang Republik Indonesia Tahun 2009 tentang Kearsipan. Keberadaan pasal-pasal tersebut menunjukkan, bahwa setiap organisasi wajib untuk menganggarkan kegiatan penyelenggaraan kearsipan secara khusus (tidak menyatu atau menumpang pada pos mata anggaran yang lain). Edwards (1980:2) tidak menyebut secara khusus pada sub bab sumberdaya, namun dia mengungkapkan arti penting pendanaan bagi implementasi kebijakan pada awal penulisan bukunya

Pada sub Prasarana dansaranateah diuraikan, bahwa inovasi yang dilakukan oleh Arsip UGM merupakan solusi bagi masalah yang dihadapi. Masalah tersebut antara lain masalah keterbatasan ruang penyimpan arsip dan dana untuk pengadaan sarana penyimpan arsip kartografi. Maka, pipa paralon merupakan bukti solusi yang digunakan oleh lembaga kearsipan tersebut.

\section{Kesimpulan}

Manajemen kearsipan merupakan kegiatan pengelolaan arsip. Penyelenggaraan terhadap kegiatan tersebut membutuhkan sistem kearsipan bagi pengelolaan arsip. Teori implementasi kebijakan publik dari Edward III menunjukkan aspek - aspek yang dapat menjadi penyebab kebijakan berhasil atau gagal diimplementasikan. Inovasi terbukti mampu menjadi solusi bagi masalah yang sempat dihadapi oleh lembaga kearsipan. Inovasi kearsipan dapat diwujudkan oleh orang-orang kreatif dan respect kepada arsip.

\section{Daftar Pustaka}

arsip.ugm.ac.id

arsip.ui.ac.id

Albrow, Martin, 2007. Birokrasi. Terjemahan M. Rusli Karim dan Totok Daryanto. Yogyakarta: Tiara Wacana 
Aziz, Abdul dan Humaizi 2013. Implementasi Kebijakan Publik Studi Tentang Kegiatan Pusat Informasi Pada Dinas Komunikasi dan Informatika Provinsi Sumatera Utara. J. Vol.3, No.1, Juni 2013. http://ojs.uma.ac.id/index.php/adminpublik/article/download/191/144

Badan Pusat Statistik. Jumlah dan Distribusi Penduduk. https://sp2010.bps.go.id/. Diakses tanggal 16 November 2018

Badan Pusat Statistik. Luas Daerah dan Jumlah Pulau Menurut Provinsi, 2002 - 2016. https:// www.bps.go.id/statictable/2014/09/05/1366/luas-daerah-dan-jumlah-pulau-menurutprovinsi-2002-2016.html. Diakses tanggal 16 November 2018

Badan Pusat Statistik. Jumlah Kecamatan Menurut Provinsi, 2004 - 2014. https://www.bps.go.id /dynamictable/2015/09/07/857/jumlah-kecamatan-menurut-provinsi-2004-2014.html.

Diakses tanggal 16 November 2018

Badan Pusat Statistik. Jumlah Desa/Kelurahan Menurut Provinsi dan Topografi Wilayah, 2003 2014. https://www.bps.go.id/linkTableDinamis/view/id/907. Diakses tanggal 16 November 2018

Buletin Khazanah, Juli 2012, 5 (2): 15-27

Direktorat Penataan Daerah, Otonomi Khusus, dan Dewan Pertimbangan Otonomi Daerah -

Direktorat Jenderal Otonomi Daerah - Kementerian Dalam Negeri Republik Indonesia, 2014. http://otda.kemendagri.go.id/CMS/Images/SubMenu/total_daerah_otonom.pdf.

Diakses tanggal 16 November 2018

Edwards III, George C., 1980. Implementing Public Policy. Washington DC: Congressional Quarterly Press

Elu, Wilfridus B. dan Purwanto, Agus Joko, 2010. Inovasi dan Perubahan Organisasi. Jakarta, Universitas Terbuka

Fitranti dan Rochmah dan Hanafi, Pelaksanaan Program Inovasi Samsat Corner Dalam Rangka Meningkatkan Pelayanan Kepada Wajin Pajak (Studi pada SAMSAT Corner Kota Malang). J. Administrasi Publik, Vol.2, No.2 : $374-380$.

Handayani, Anita. Kode Arsip Statis UGM. http://anitanet.staff.ipb.ac.id/arsiparis/kode-arsip-statiskartografi-ugm/

http://law.ui.ac.id/v3/pelatihan-pengelolaan-arsip-dinamis-di-lingkungan-fhui/

https://kbbi.web.id/inovasi

https://kbbi.web.id/manajemen

https://ugm.ac.id/en/berita/8208-pelantikan.forsipagama.dan.penghargaan.petugas.kearsipan.

meriahkan.peringatan.dies.ix.arsip.ugm

https://biroumum.kemdikbud.go.id/web/files/SPAD_Operator_Unit_Satker.pdf 
Ikawati, Yuni dan Setiawati, Dwi Ratih, 2009. Survei dan Pemetaan Nusantara, Badan Koordinasi Survei dan Pemetaan Nasional bekerjasama dengan Masyarakat Penulis Ilmu Pengetahuan dan Teknologi, Jakarta

Islamy, M. Irfan, 2014. Prinsip-prinsip Perumusan Kebijaksanaan Negara. Jakarta: PT Bumi Aksara

Kast, Fremont E. and Rosenzweig, James E., 1990. Organisasi dan Manajemen. Terjemahan A. Hasymi Ali. Jakarta: Bumi Aksara

Kiwang, Amir Syarifudin dan Pandie, David B.W. dan Gana, Frans, Kebijakan Publik dan Efektivitas Organisasi. J.Kebijakan Publik Vol 5, No.1, Maret 2014. 31 - 36

Kurniatun, 2013. Pendampingan dan Pengembangan RecordsCenter Unit Kerja Sebagai Upaya Pembinaan Kearsipan di Lingkungan Universitas Gadjah Mada

Magetsari, Nurhadi, 2008. Organisasi dan Layanan Kearsipan. J. Kearsipan, Vol.3, No.1, Desember 2008

Moleong, 2010. Metodologi Penelitian Kualitatif. Bandung: PT Remaja Rosda Karya

Ricks, Betty R. and Swafford, Ann J. and Gow, Kay E. 1992. Information and Image Management: A Records Systems Approach. Cincinnati, Ohio:South-Western Publishing Co.

Robbins, Stephen P. and Judge, Timothy A. 2007. Organizational Behavior. New Jersey: Pearson Education

Suhana, 2016. Pengelolaan Sumber Daya Manusia dan Ruang Penyimpan Arsip Dalam Melakukan Kegiatan Pengelolaan Kearsipan di Pusat Reaktor Serba Guna. Buletin Pengelolaan Reaktor Nuklir, Vol.13, No.1, April 2016

Sukoco, 2007. Manajemen Administrasi Perkantoran Modern. Jakarta: Erlangga

Sumrahyadi, 2016. Usaha Meningkatkan Kuantias dan Kualitas Sumber Daya Manusia Kearsipan. http://www.sumrahyadi.com/2016/03/usaha-meningkatkan-kualitas-dan.html. Diakses tanggal 5 Maret 2017

Suwarno, Yogi. Diakses tanggal 8 Agustus 2011. Inovasi di Sektor Publik. http://www.ucs.mun.ca/-resxty/business1000/glossary. Diunduh tanggal 16 November 2018

Suwitri, Sri, 2011. Konsep Dasar Kebijakan Publik. Semarang: Badan Penerbit Universitas Diponegoro 